\title{
Consumer Buying Behaviour towards Life Insurance Policies in Thanjavur City
}

\author{
Guru.P, Umamaheswari.D
}

\begin{abstract}
The typical promotion of life insurance policies is very less in India than any other countries. Despite being among one of the world's highest population, the insurance industry in India serves as a high catchment for several foreign and Indian insurance companies in escalating their promotion and share in the market, the typical selling is much lesser. Prior to the aperture of Indian insurance market for the invasion of foreign insurance companies, Life Insurance Corporation (LIC) was the only insurance company that dealt with Life Insurance. Furthermore by giving opportunity for other private insurance companies in Indian market, all the global giants in life insurance has commenced business in our country. Using their knowledge about the global market and their associations, these multinational companies have offered numerous lucrative schemes to attract consumers at various levels in India but regrettably unsuccessful to acquire the main share in the Indian market. Despite all the odds, still LIC is the major player in the life insurance market with approximately more than sixty five percent of share in the market. Still it is a wonder about the reason behind why the consumers in India are not convinced of on various private companies and why still majority of the people in India have not insured their life. This research is an attempt to examine the factors that determines the consumer buying behavior of life insurance policies. This paper emphasizes on the consumers buying behaviour of life insurance policies in Thanjavur City. 150 samples were chosen by convenience sampling technique. A structured questionnaire was administered for this purpose and the data collected were analysed using chi-square and regression.
\end{abstract}

Index Terms: Buying Behaviour, Chi-Square, Life Insurance Regression

\section{INTRODUCTION}

As an individual each person possesses certain amount of risk from various sources. Consumers in India are mainly inclined towards various poignant aspects; however at the same time the purchase behaviour is mainly influenced based on the rational factors. At the same time, it has a single responsibility. Typical Indian consumers consider the future and struggle to make a healthier and safer life for his dependents in the future. Life insurance includes the following parts: risk coverage and savings. Insurance is the best option to cover savings and risks for a middle class employee. But in India, insurance is often taken as a tax exemption, instead of a long-term financial plan. Indians tend to spend on real estate and jewel, bank balances and surveillance. They can also invest in stocks but the percentage is very low.

Revised Manuscript Received on July 05, 2019

Guru.P, Research Scholar, Department of Management Studies, Periyar Maniammai Institute of Science \& Technology, Thanjavur, India.

Umamaheswari. D, Department of Management Studies, Periyar Maniammai Institute of Science \& Technology, Thanjavur, India.

\section{REVIEW OF LITERATURE}

Antony Beckett et al., (2000) explained that the innovative technology has formed extremely aggressive market conditions that can significantly affect consumer buying behaviour towards financial sector. Researcher pointed out that those service providers must understand the various customer influencers.

Kyoko Fukakawa (2012) investigated the possibility of ethically dubious consumer behaviour based on data from 72 British visitors. Sandeep Chaudary (2016) explored six factors that influenced consumer behaviour, including personal and current services, improved business, customer service, improved service quality, concrete benefits, and efficient customer management. The study concluded that consumer buying behaviour is influenced by new and innovative products and better customer relationship management. A sample of 100 respondents was used for this study.

Guru and Umamaheswari (2018) in their research concluded that among the various other factors, the major variables that control the insight of the consumers towards life insurance policies positively were quality of the service offered, relationship between the client and company and reputation of the company. The growth rate of insurance industry in India is faster and hence it has become significant for the insurance companies to identify and comprehend the factors that persuade the perception of the consumers and the same can be utilized as the supportive feature in developing fresh and pioneering items which meet the consumer's expectation.

Guru and Umamaheswari (2019) in their research on factors deciding selection of policies of private life insurance companies among consumers in Thanjavur District explored that Price, product uniqueness, accessibility and promotions impacts the purchase decision of consumers upon the various policies of private life insurance companies significantly and positively. The agents are supposed to provide better and accurate services and settle claims without any delay or issues. Private life insurance companies are required to appreciate precisely the financial needs of consumers and should set easy and uncomplicated terms and conditions for purchasing their life insurance policies. In addition, private life insurance companies have to bring in different innovative products to fulfill needs of various consumer segments.

\section{METHODOLOGY}

\section{A. Objectives}

- To analyse the relationship between quality of service offered by the company and the buying behaviour of the consumers

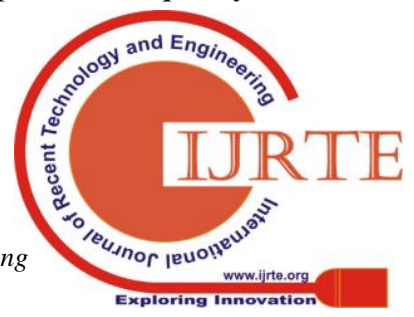


- To measure the association between easy procedures implemented by the organisation and buying behaviour

- To analyse the relationship among loyalty and the purchase behaviour of the consumers

\section{B. Research Design}

A structured questionnaire was administered to interview and collect data from 150 samples using convenience sampling method in Thanjavur City. The data collected were analyzed using descriptive statistics, chi-square and regression.

\section{RESULTS AND DISCUSSION}

\section{A. Descriptive Statistics}

Using descriptive statistics, it is shown that nearly $34.7 \%$ of the consumers are in the category of 21 to 30 years of age, $58.7 \%$ of them were male, $58.7 \%$ of them have completed professional course, $58.7 \%$ of the respondents have been married, $35.3 \%$ of the respondents were earning in the range of Rs 30,001 - Rs 45,000, 64.7\% of them were in Joint Family and $41.3 \%$ of them having a total experience of $3-7$ years.

\section{B. Chi-Square Test}

\section{Hypothesis 1}

Null hypothesis: There exists no statistical difference between quality of service and buying behavior

\begin{tabular}{|c|c|c|c|c|c|c|}
\hline \multirow{2}{*}{} & \multicolumn{5}{c|}{ Case Processing Summary } \\
\cline { 2 - 7 } & \multicolumn{2}{|c|}{ Valid } & \multicolumn{2}{c|}{ Missing } & \multicolumn{2}{c|}{ Total } \\
\cline { 2 - 7 } & $\mathbf{N}$ & $\begin{array}{c}\text { Perce } \\
\text { nt }\end{array}$ & N & $\begin{array}{c}\text { Perce } \\
\text { nt }\end{array}$ & N & $\begin{array}{c}\text { Perc } \\
\text { ent }\end{array}$ \\
\hline $\begin{array}{c}\text { Quality of } \\
\text { Service * } \\
\text { Buying }\end{array}$ & 150 & $100 \%$ & 0 & $0.0 \%$ & 150 & $\begin{array}{c}\% \\
\text { Behaviour }\end{array}$ \\
\end{tabular}

Quality of Service * Buying Behaviour - Cross

Tabulation

Count

\begin{tabular}{|cc|c|c|c|c|c|}
\hline & & \multicolumn{4}{|c|}{ Behaviour } & \multirow{2}{*}{ Total } \\
\cline { 3 - 6 } & & $\begin{array}{c}\text { Disag } \\
\text { ree }\end{array}$ & $\begin{array}{c}\text { Neut } \\
\text { ral }\end{array}$ & $\begin{array}{c}\text { Ag } \\
\text { ree }\end{array}$ & $\begin{array}{c}\text { Strongl } \\
\text { y Agree }\end{array}$ & \\
\hline & Disagree & 24 & 9 & 0 & 0 & 33 \\
Quality & Neutral & 0 & 9 & 0 & 0 & 9 \\
of & Agree & 0 & 9 & 18 & 9 & 36 \\
Service & Strongly & 0 & 0 & 18 & 54 & 72 \\
Total & Agree & $\mathbf{2 4}$ & $\mathbf{2 7}$ & $\mathbf{3 6}$ & $\mathbf{6 3}$ & $\mathbf{1 5 0}$ \\
\hline
\end{tabular}

(a) 4 cells $(25.0 \%)$ have expected count less than 5 . The minimum expected count is 1.44 .

It can be understood from the above table that the $\mathrm{p}$-value is 0.00 is less than the $5 \%$ significance level, hence reject the alternate hypothesis. Therefore it is clear that there is a statistical difference between quality of service and buying behaviour.

\section{Hypothesis 2}

Null hypothesis: There exists no statistical difference between easy procedure and buying behaviour

Case Processing Summary

\begin{tabular}{|c|c|c|c|c|c|c|}
\hline \multirow{2}{*}{} & \multicolumn{6}{|c|}{ Cases } \\
\cline { 2 - 7 } & \multicolumn{2}{|c|}{ Valid } & \multicolumn{2}{c|}{ Missing } & \multicolumn{2}{|c|}{ Total } \\
\cline { 2 - 7 } & $\mathbf{N}$ & $\begin{array}{c}\text { Perce } \\
\text { nt }\end{array}$ & $\mathbf{N}$ & $\begin{array}{r}\text { Perc } \\
\text { ent }\end{array}$ & N & $\begin{array}{c}\text { Perce } \\
\text { nt }\end{array}$ \\
\hline $\begin{array}{c}\text { Easy procedure } \\
\text { * Buying } \\
\text { Behaviour }\end{array}$ & 150 & $100 \%$ & 0 & $0.0 \%$ & 150 & $100 \%$ \\
\hline
\end{tabular}

Easy procedure * Buying Behaviour Cross tabulation Count

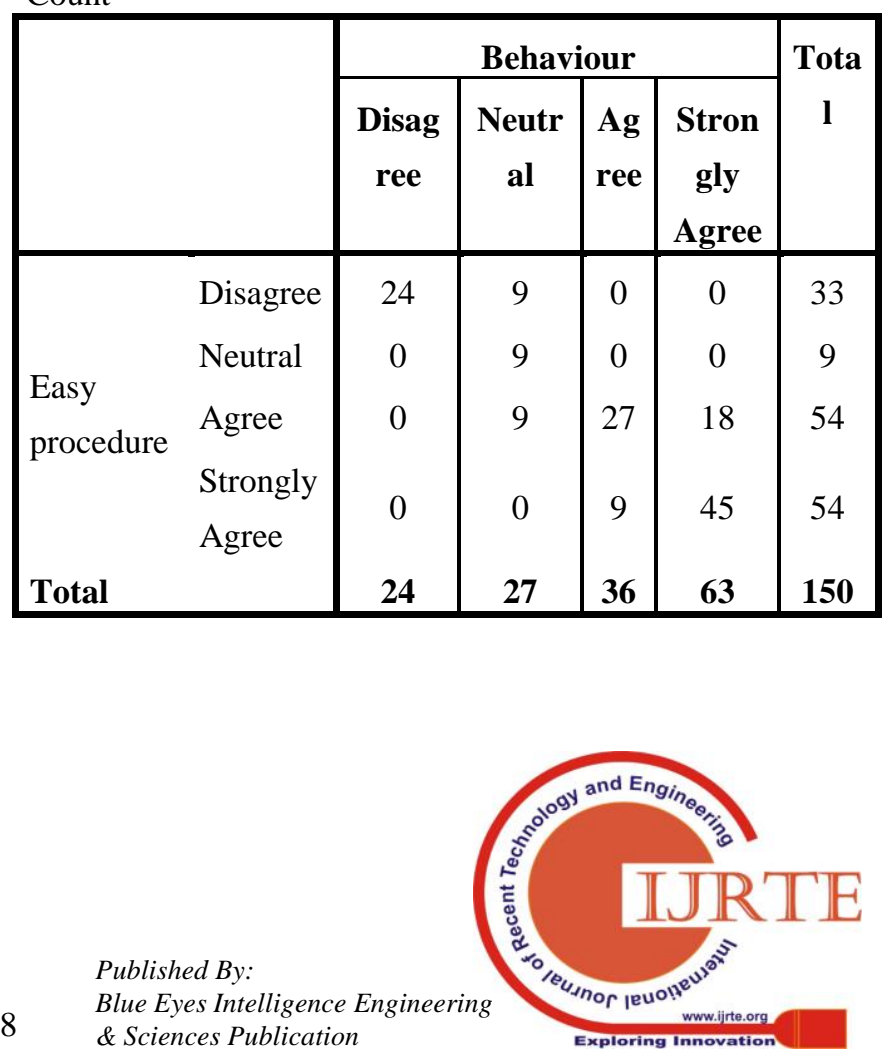


Chi-Square Tests

\begin{tabular}{|l|r|r|r|}
\hline & \multicolumn{1}{|c|}{ Value } & \multicolumn{1}{|c|}{ df } & \multicolumn{1}{|c|}{$\begin{array}{c}\text { Asymp. Sig. } \\
\text { (2-sided) }\end{array}$} \\
\hline $\begin{array}{l}\text { Pearson } \\
\text { Chi-Square } \\
\text { Likelihood Ratio } \\
\begin{array}{l}\text { Linear-by-Linear } \\
\text { Association }\end{array}\end{array} 197.132^{\mathrm{a}}$ & 196.055 & 9 & .000 \\
N of Valid Cases & 15.977 & 1 & .000 \\
\hline
\end{tabular}

(a) 4 cells $(25.0 \%)$ have expected count less than 5 . The minimum expected count is 1.44 .

It can be understood from the above table that the p-value is 0.00 is less than $5 \%$ significance level, hence reject the alternate hypothesis. Therefore it is clear that there is a statistical difference between easy procedure and buying behavior.

\section{Hypothesis 3}

Null: There exists no statistical difference between company loyalty and buying behaviour.

Case Processing Summary

\begin{tabular}{|l|r|r|r|r|r|r|}
\hline \multirow{1}{*}{} & \multicolumn{6}{|c|}{ Cases } \\
\cline { 2 - 7 } & \multicolumn{2}{|c|}{ Valid } & \multicolumn{2}{|c|}{ Missing } & \multicolumn{2}{|c|}{ Total } \\
\cline { 2 - 7 } & $\begin{array}{r}\text { N } \\
\text { ent }\end{array}$ & $\begin{array}{r}\text { N } \\
\text { Perce } \\
\text { nt }\end{array}$ & N & $\begin{array}{r}\text { Perce } \\
\text { nt }\end{array}$ \\
\hline $\begin{array}{l}\text { Company } \\
\text { loyalty } \\
\text { Buying } \\
\text { behaviour }\end{array}$ & 150 & $\begin{array}{r}100 \\
\%\end{array}$ & 0 & $0.0 \%$ & 150 & $100 \%$ \\
\hline
\end{tabular}

Company Loyalty * Buying Behaviour Cross tabulation Count

\begin{tabular}{|ll|c|c|c|c|c|}
\hline \multirow{2}{*}{} & & \multicolumn{4}{|c|}{ Buying Behaviour } & \multirow{2}{*}{ Total } \\
\cline { 3 - 6 } & & $\begin{array}{c}\text { Disag } \\
\text { ree }\end{array}$ & $\begin{array}{c}\text { Neut } \\
\text { ral }\end{array}$ & $\begin{array}{c}\text { Ag } \\
\text { ree }\end{array}$ & $\begin{array}{c}\text { Strongl } \\
\text { y Agree }\end{array}$ & \\
\hline \multirow{2}{*}{ Compan } & Disagree & 24 & 9 & 0 & 0 & 33 \\
y & Agutral & 0 & 18 & 9 & 0 & 27 \\
Loyalty & Strongly & 0 & 0 & 18 & 18 & 36 \\
& Agree & 0 & 9 & 45 & 54 \\
Total & & $\mathbf{2 4}$ & $\mathbf{2 7}$ & $\mathbf{3 6}$ & $\mathbf{6 3}$ & $\mathbf{1 5 0}$ \\
\hline
\end{tabular}

Chi-Square Tests

\begin{tabular}{|l|r|r|r|}
\hline & \multicolumn{1}{|c|}{ Value } & \multicolumn{1}{|c|}{ df } & \multicolumn{1}{|c|}{$\begin{array}{c}\text { Asymp. Sig. } \\
\text { (2-sided) }\end{array}$} \\
\hline $\begin{array}{l}\text { Pearson } \\
\text { Chi-Square } \\
\text { Likelihood Ratio } \\
\text { Linear-by-Linear } \\
\text { Association } \\
\text { N of Valid Cases }\end{array}$ & 221.009 & 9 & .000 \\
\hline
\end{tabular}

(a) 2 cells $(12.5 \%)$ have expected count less than 5 . The minimum expected count is 4.32 .

It can be understood from the above table that the $\mathrm{p}$-value is 0.00 is less than $5 \%$ significance level, hence reject the alternate hypothesis. Therefore it is clear that there is a statistical difference between company loyalty and buying behavior.

\section{Regression}

ANOVA $^{\mathrm{a}}$

\begin{tabular}{|rl|r|r|r|l|l|}
\hline \multicolumn{2}{|l|}{ Model } & $\begin{array}{r}\text { Sum of } \\
\text { Squares }\end{array}$ & df & \multicolumn{1}{c|}{$\begin{array}{c}\text { Mean } \\
\text { Square }\end{array}$} & F & Sig. \\
\hline \multirow{2}{*}{1} & Regression & 154.739 & 3 & 51.580 & 248.529 & $.000^{\mathrm{b}}$ \\
& Residual & 30.301 & 146 & .208 & & \\
& Total & 185.040 & 149 & & & \\
\hline
\end{tabular}

(a) Dependant Variable: Buying Behaviour

(b) Predictors: (Constant), Company Loyalty, Easy procedure, Quality of service

From the above ANOVA table, it was found that regression value is less than 0.05 . That shows that the regression table is significant.

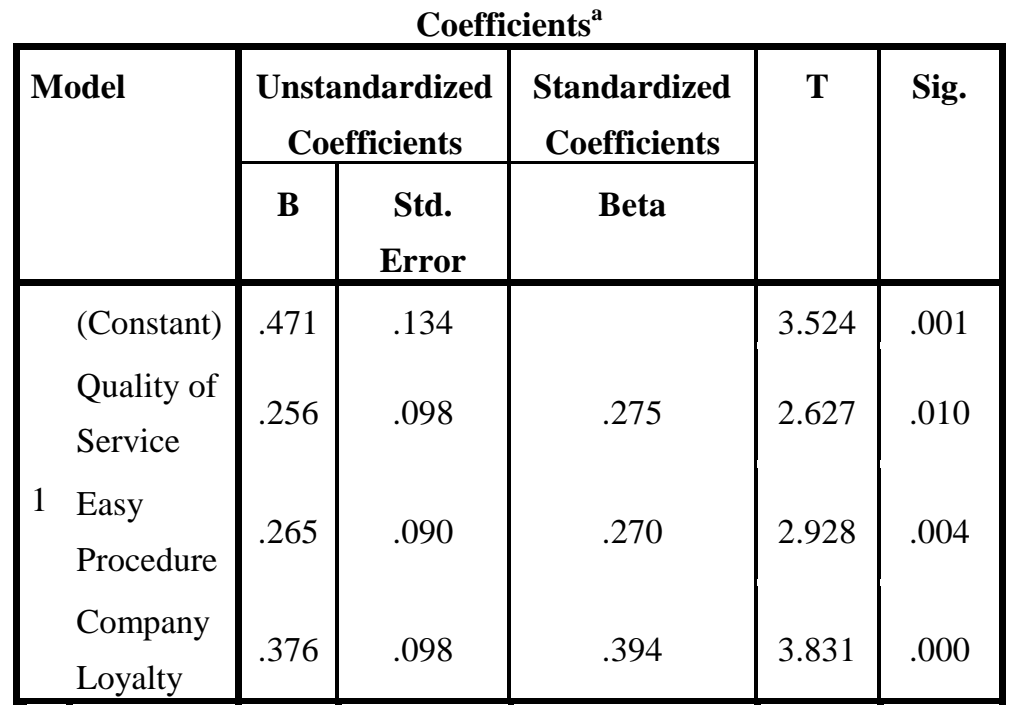

(a) Dependent Variable: Buying Behaviour

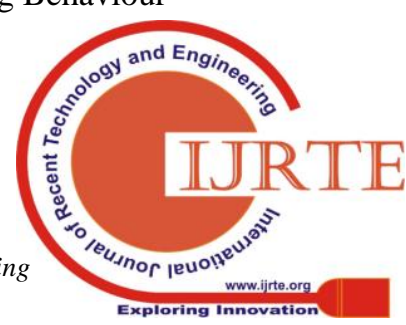


The regression coefficients can be framed as

$\mathrm{Y}($ Buying Behaviour $)=0.471+0.256$ (Quality of Service $)$ +0.265 (Easy procedure $)+0.376$ (Company loyalty)

\section{CONCLUSION}

From the above analysis it is concluded that the major factors like service quality, easy of procedures and company loyalty are possessing significant impact on the consumer's buying behaviour on life insurance policies. Furthermore this shows that all these variables creates a significant impact on the purchase behaviour. The life insurance companies need to focus on these aspects in order to enhance the consumer's buying behaviour on the life insurance products.

\section{REFERENCES}

1. Antony Beckett, Paul Hewer, Barry Howcroft, "An exposition of consumer behaviour in the financial services industry", International Journal of Bank Marketing, 18(1), 2000, pp.15-26.

2. Dipin Mathur and Ashish Tripathi, Factors Influencing Customer's Choice for Insurance companies - A Study of Ajmer City", IOSR Journal of Business and Management, 16(2), 2014.

3. Fukukawa, K, "Developing a framework for Ethically Questionable Behavior in Consumption", Journal of Business Ethics, 2002.

4. Guru.P and Umamaheswari.D, "A study on factors deciding selection of policies of private life insurance companies among consumers in Thanjavur District", International Journal of Recent Technology and Engineering, 7(6S2), 2019, pp.45-48.

5. Guru.P and Umamaheswari.D, "An Empirical Investigation to analyse the Factors influencing the Consumer Perception regarding Life Insurance policies using Path Analysis", International Journal Supply Chain Management, 7(5), 2018, pp.927-932.

6. Narender S and Sampath L, "Consumer awareness towards life insurance sector in India", Abhinav's International refereed Journal of research in Management and Technology, 3(3), 2014.

7. Sandeep Chaudhary, "Consumer Perception regarding Life Insurance Policies: A Factor analytical Approach", Pacific Business Review International, 9(6), 2016.

8. Vijaya Ragunathan M, "A Study on Consumer Behavior Towards Life Insurance Products With Reference To IDBI Fortis Company Limited, Dindigul District", International Journal of Applied science, 6(8), 2016. 